\title{
Tissue interactions affecting the migration and differentiation of neural crest cells in the chick embryo
}

\author{
CLAUDIO D. STERN ${ }^{1}$, KRISTIN B. ARTINGER $^{2}$ and MARIANNE BRONNER-FRASER ${ }^{2}$ \\ ${ }^{1}$ Department of Human Anatomy, South Parks Road, Oxford OXI 3QX, UK \\ ${ }^{2}$ Developmental Biology Center, University of California, Irvine, CA 92717, USA
}

\begin{abstract}
Summary
A series of microsurgical operations was performed in chick embryos to study the factors that control the polarity, position and differentiation of the sympathetic and dorsal root ganglion cells developing from the neural crest. The neural tube, with or without the notochord, was rotated by $180^{\circ}$ dorsoventrally to cause the neural crest cells to emerge ventrally. In some embryos, the notochord was ablated, and in others a second notochord was implanted. Sympathetic differentiation was assessed by catecholamine fluorescence after aldehyde fixation.

Neural crest cells emerging from an inverted neural

motor axons appear also to be attracted to the notochord until they reach its immediate vicinity. The dorsal root ganglia always form adjacent to the neural tube and their dorsoventral orientation follows the direction of migration of the neural crest cells. Differentiation of catecholaminergic cells only occurs near the aorta/ mesonephros and in addition requires the proximity of either the ventral neural tube (floor plate/ventral root region) or the notochord. Prior migration of presumptive catecholaminergic cells through the sclerotome, however, is neither required nor sufficient for their adrenergic differentiation.
\end{abstract} tube migrate in a ventral-to-dorsal direction through the sclerotome, where they become segmented by being restricted to the rostral half of each sclerotome. Both motor axons and neural crest cells avoid the notochord and the extracellular matrix that surrounds it, but

Key words: neural crest, chick embryo, sympathetic nervous system, catecholamines, adrenergic neurons, differentiation, segmentation.

\section{Introduction}

The neural crest is a migratory cell population, which originates in the neural tube. After closure of the neural tube, neural crest cells emigrate from its dorsal margin and proceed along characteristic pathways to reach their final destinations, where they give rise to diverse derivatives including most neurons and glia of the peripheral nervous system. The premigratory neural crest is widely acknowledged to be a pluripotent population of cells (see Le Douarin et al. 1977, 1979; Le Lièvre et al. 1980; Sieber-Blum and Cohen, 1980; Le Douarin, 1982; Bronner-Fraser and Fraser, 1988, 1989; Serbedzija et al. 1989); the fates of neural crest cells are thought to be determined largely by interactions with surrounding cells. These interactions are likely to occur during their migration and/or when neural crest cells reach their various destinations in the embryo. Neural crest migratory pathways (Weston, 1963; Le Douarin and Teillet, 1973; Le Douarin, 1982; Rickmann et al. 1985; Bronner-Fraser, 1986; Loring and Erickson, 1987; Teillet et al. 1987; Lallier and Bronner-Fraser, 1988), final destinations and developmental fates (reviewed by Le Douarin, 1982) are well documented. However, the

mechanisms that govern the route and direction taken by individual migrating trunk neural crest cells and the cell interactions that determine cell fates are poorly understood.

In the trunk of avian embryos, neural crest cells migrate along two primary pathways: one lateral, between the dermomyotome and the ectoderm (followed by presumptive melanocytes), and the other ventral and medial, through the rostral half of each sclerotome (followed by precursors of dorsal root and sympathetic ganglia and adrenal chromaffin cells). The neural crest cells remaining in the sclerotome later give rise to the dorsal root ganglia (Weston, 1963; Le Douarin, 1982; Rickmann et al. 1985; Teillet et al. 1987; Lallier and Bronner-Fraser, 1988). In adult vertebrates, all the components of the peripheral nervous system (PNS) that lie close to the vertebral column are arranged in a metameric fashion. In the embryo, both the motor nerves and the neural crest cells are restricted to the rostral half of each sclerotome (reviewed by Keynes and Stern, 1988).

Neural crest cells also have a characteristic pattern of migration in the dorsoventral plane. In a classic paper, Weston (1963) demonstrated that when the neural tube 
is rotated dorsoventrally by $180^{\circ}$ to cause neural crest cells to emerge ventrally, neural crest cells migrate in two streams: one dorsally, in reverse direction to that taken normally and the other ventrally towards the aorta. Dorsal root ganglia develop in such embryos. From this experiment, Weston concluded that the neural crest cells are probably not directed to their targets by chemoattractants but rather that they exploit all the spaces available to them. However, Weston's experiments were conducted before it was known that the normal pathways of neural crest migration through the sclerotome were restricted to the rostral half.

Here, we have repeated and extended Weston's experiment and performed notochord ablation and implantation experiments to address several questions about the pathways of migration and the tissue interactions that govern neural crest cell development. In particular, we investigate whether cells migrating in a ventral-to-dorsal direction through the sclerotome are segmentally restricted to the rostral half. We also study whether the position and orientation of the dorsal root ganglia are determined by the neural tube from which they arise or by the sclerotome through which they migrate. In addition, we explore the influence of the neural tube and notochord on the direction of growth of ventral root axons. Finally, we examine whether ventrally emerging neural crest cells can differentiate into sympathetic (catecholaminergic) cells and the roles played by the orientation of the neural tube and by the notochord in such adrenergic differentiation.

\section{Materials and methods}

\section{Embryos and microsurgery}

Hens' eggs (White Leghorn) were incubated at $37^{\circ} \mathrm{C}$ until the embryos reached stages 12-13 (Hamburger and Hamilton, 1951). Operations were performed as described previously (Stern and Keynes, 1987). Briefly, a window was cut in the egg shell with a scalpel blade and the yolk floated with calciumand magnesium-free Tyrode's saline (CMF). Indian ink (Pelikan Fount India), diluted 1:10 in CMF, was then injected under the blastoderm to aid visualization of the embryo. A standing drop of CMF containing $0.1 \%$ trypsin was added to facilitate dissection. The vitelline membrane over the graft site was penetrated with a tungsten needle; operations were performed using a microsurgical knife (Weck, $15^{\circ}$ angle), tungsten needles and fine Dewecker's scissors. A carmine mark was sometimes placed at one end of the graft. After the operation, a few drops of penicillin and streptomycin solution were added, the eggs sealed with PVC tape and incubated in a humidified atmosphere at $38^{\circ} \mathrm{C}$ until the time of fixation $(5 \mathrm{~h}$ to $5 \mathrm{~d}$ after the operation).

\section{Neural tube inversion about its dorsoventral axis} A length of neural tube, sometimes including the underlying notochord, equivalent in length to 4-12 segments $(400-1200 \mu \mathrm{m})$, was excised from a region extending caudally from the three most recently formed somites (Fig. 1A-D). After $180^{\circ}$ rotation about the dorsoventral axis, this tissue was grafted to the same axial level, either in the same embryo or in a host of equivalent stage. Control embryos were treated identically, except that the neural tubes were grafted in their original orientation.
In some experiments, the host notochord was not excised with the neural tube but left in its original position. A donor neural tube and notochord were then grafted in reversed dorsoventral orientation, so that the operated embryo now had two notochords, one in its original position and the other dorsal to the grafted neural tube (Fig. 1D).

\section{Notochord ablation}

After separating the somites on each side of the embryo from the neural tube, a length of notochord, spanning most of the rostrocaudal extent of the segmental plates, was excised (Fig. 1E).

\section{Notochord grafts}

A deep cut was made into the 5-8 most recently formed somites of a host embryo. An equivalent length of notochord was excised from a donor embryo, its orientation marked with carmine, and implanted into the groove made in the host embryo, with preserved rostrocaudal orientation (Fig. 1F). In control embryos, a similar groove was cut into the somites of the embryo, but no graft was placed in it.

\section{Histology}

To visualise catecholaminergic cells, the aldehyde-induced histofluorescence technique of Sechrist et al. (1989) was employed. Embryos were fixed overnight in $4 \%$ paraformaldehyde containing $0.25 \%$ glutaraldehyde and then washed extensively in phosphate-buffered saline (PBS). The embryos were then placed in $5 \%$ sucrose in PBS and transferred to $15 \%$ sucrose in PBS, where they were left to equilibrate overnight at $4{ }^{\circ} \mathrm{C}$. They were then embedded in $7.5 \%$ gelatin (300-Bloom) in $15 \%$ sucrose/PBS. After rapid freezing in isopentane cooled with liquid nitrogen, $14 \mu \mathrm{m}$ sections were cut with a Zeiss Micron cryostat. The sections were examined by epifluorescence microscopy using an Olympus Vanox-T microscope with violet excitation filters. After examination and photography, most of these embryos were processed for HNK-1 immunohistochemistry as described below.

Other embryos (for HNK-1 immunohistochemistry alone) were fixed for $1.5-3 \mathrm{~h}$ in Zenker's fixative, washed in running water and placed in $70 \%$ ethanol. The embryos were then dehydrated in a graded series of alcohols, placed in three changes of histosol and embedded in fresh paraplast for sectioning $(10 \mu \mathrm{m})$.

\section{Immunohistochemistry}

The monoclonal antibody HNK-1 was used as a marker for neural crest cells (Tucker et al. 1984). Sections of paraffin embedded embryos were immersed in histosol to remove the paraffin wax, hydrated through a graded series of ethanols, and washed in PBS. Cryostat and hydrated paraffin sections were incubated in undiluted culture medium supernatant from HNK-1 hybridoma cells for $3 \mathrm{~h}$ at room temperature. After washing in phosphate buffer, slides were incubated with rabbit anti-mouse IgM (Zymed; diluted $1: 30$ in $0.1 \%$ BSA in PBS) for $1 \mathrm{~h}$, followed by a $1 \mathrm{~h}$ incubation with rhodamineconjugated goat anti-rabbit IgG serum (Zymed; diluted 1:30 in $0.1 \%$ BSA in PBS). For some paraffin sections, fluorescein-conjugated second antibody was substituted. The slides were washed in PBS, mounted under a coverslip in buffered glycerol ( $90 \%$ glycerol $/ 10 \% 0.5 \mathrm{~m}$ sodium carbonate, $\mathrm{pH} 7.8$ ), and observed using epifluorescence optics. In a series of control slides, the primary antibody was omitted; no fluorescence was observed in these cases. 


\section{Results}

The results presented are based on 83 embryos that survived the operations for the desired period of time. Operated and control embryos were fixed after various periods of incubation ranging from $5 \mathrm{~h}$ to $5 \mathrm{~d}$. The results are summarised in the right halves of the diagrams in Fig. 1, where these pathways are shown by blue arrows. In 9 cases, embryos were used to provide more than one result. For example, in cases of neural tube and notochord rotation about their dorsoventral axis, regions closer to the graft-host junction might contain two notochords, one dorsal and the other ventral, on either side of the rotated neural tube, while regions in the middle of the rotated piece would only contain the rotated neural tube and notochord.

The results presented below, obtained from 108 operations, are divided according to the stage at which the embryos were fixed. One group of embryos was fixed after 5-24 $\mathrm{h}$ incubation (stages 15-18) to observe the early stages of migration of neural crest cells. A second group of embryos was fixed after $24-48 \mathrm{~h}$ (stages 18-22) to study the motor axons and primordia of the dorsal root ganglia and autonomic nervous system, and a third group was fixed after more than 2 days' incubation (stages 22-27) to locate catecholaminergic cells.

Effects of dorsoventral inversion of the neural tube on the pattern of neural crest cell migration (embryos fixed at stages 15-18)

Embryos in which the neural tube and notochord had been rotated $180^{\circ}$ about their dorsoventral axis were fixed 5-24h after the operation ( $n=9)$, sectioned and stained with monoclonal antibody HNK-1 to observe the pathways taken by neural crest cells. HNK-1 immunoreactive cells emerged from the ventral (original dorsal) margin of the tube. Some cells had entered the sclerotomes and migrated dorsally while others had migrated ventrally to surround the dorsal aorta (Fig. 2A). In serial transverse sections, the distribution of HNK-1 positive cells in the sclerotome appeared metameric, with several adjacent sections containing HNK-1-immunoreactive cells in the rostral sclerotome and around the aorta, followed by an equivalent number of sections with HNK-1-immunoreactive cells only around the dorsal aorta and absent from the caudal sclerotome. Thus, the pattern of neural crest migration through the sclerotome appears to be segmentally restricted to the rostral half of the sclerotome regardless of the position at which they emerged. No HNK-1immunoreactive cells were observed either in the dermomyotome or in the vicinity of the rotated notochord, which now occupied a dorsal position within the embryo.

In a control series of experiments $(n=6)$, the notochord and neural tube were removed and replaced without rotation. In two of these embryos, the neural tube was slightly open in some portions of the operated region, while other regions of the graft appeared normal. However, all embryos displayed a distribution of HNK-1-positive cells indistinguishable from those observed in unoperated embryos or in unoperated regions of the same embryos (Fig. 2B).

In one embryo, the neural tube was rotated $180^{\circ}$ about its dorsoventral axis while the notochord was left in its original position. After histology, the notochord was found to be located slightly to the right of the inverted neural tube. HNK-1-immunoreactive cells were found around the dorsal aorta and in the rostral halves of the sclerotomes on the right side of the embryo. However, they were not seen in the sclerotomes to the left of the operated region (Fig. 2C), suggesting that the notochord prevents neural crest cell migration.

In another embryo, the neural tube was rotated $180^{\circ}$ about its dorsoventral axis in the absence of both host and donor notochord. In this case, HNK-1-immunoreactive cells were observed around the dorsal aorta and throughout the rostral halves of the sclerotomes, as in embryos where both the notochord and neural tube had been reversed. In addition, many HNK-1-imunoreactive cells were seen in the region dorsal to the neural tube (Fig. 2D). This is in contrast to the pattern seen when the notochord was present on either the dorsal or the ventral aspects of the embryo (see Fig. 2A-C), in which HNK-1-immunoreactive cells were absent from the regions surrounding the notochord.

\section{Effects of notochord ablation or implantation on the distribution of neural crest derivatives and motor axons (embryos fixed at stages 21-22)}

In order to examine the effects of the notochord on neural crest cell migration and ganglion formation, the notochord was removed by surgical ablation $(n=21$ embryos) or an extra notochord was implanted next to that of the host ( $n=12$ embryos); in both cases, the neural tube was left in its normal dorsoventral orientation. In all these embryos, the dorsal root and sympathetic ganglia were indistinguishable from those of unoperated embryos.

The presence of the notochord and its surrounding extracellular matrix influenced the positions taken by some migrating neural crest cells and by motor axons. In some cases of notochord ablation (including regions close to the stump of the notochord remaining after partial ablation), the notochord was absent but the HNK-1-immunoreactive perinotochordal matrix was still visible. The positions taken by migrating neural crest cells and the ventral roots always respected this matrix, regardless of whether the notochord was still within it or not. When the matrix was present, HNK-1 positive cells were found bilaterally on either side of this matrix (Figs 3, 4). When absent, HNK-1 positive cells were found crossing the ventral midline of the embryo. Similar results were obtained from embryos in which the neural tube had been rotated about its dorsoventral axis (Fig. 1B,C,E); in these embryos, neural crest cells failed to cross the midline in the presence of a notochord and/or HNK-1 immunoreactive perinotochordal matrix but did cross in its absence. 

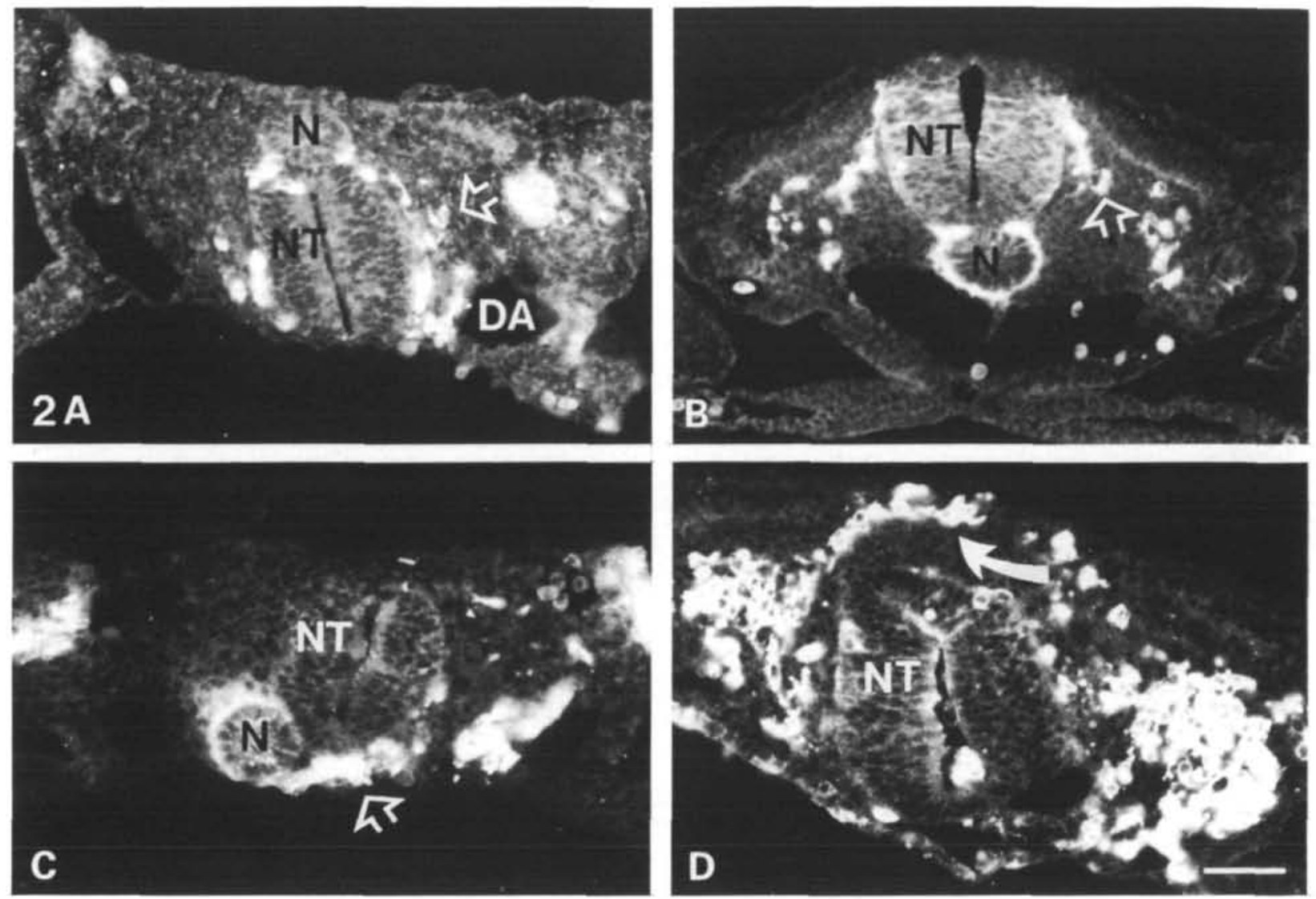

Fig. 2. Fluorescent photomicrographs of transverse sections through operated embryos fixed 1 day after grafting and stained with monoclonal antibody HNK-1. (A) Embryo in which the neural tube (NT) and notochord (N) were inverted $180^{\circ}$ dorsoventrally. Neural crest cells were observed within the rostral sclerotome (arrow) and around the dorsal aorta (DA). (B) Embryo in which the neural tube and notochord were excised and reimplanted in their original orientation. Neural crest cells are observed along their normal pathways in the sclerotome (arrow). (C) Embryo in which the neural tube was rotated $180^{\circ}$ about its dorsoventral axis but the host notochord was left in its normal site. Neural crest cells that emerged from the ventral portion of the neural tube (arrow) are only found in the right side of the embryo. (D) Embryo in which the neural tube was rotated $180^{\circ}$ dorsoventrally and the notochord was extirpated. Neural crest cells are found in the sclerotome and above the dorsal neural tube subjacent to the ectoderm (curved arrow). Scale bar represents $60 \mu \mathrm{m}$ (A), $50 \mu \mathrm{m}$ (B), $45 \mu \mathrm{m}$ (C), $40 \mu \mathrm{m}$ (D).

In embryos in which a second notochord had been grafted adjacent to the host notochord ( $n=12 \mathrm{em}-$ bryos), the dorsal root and sympathetic ganglia formed normally. However, a supernumerary ventral root region often formed between the two notochords (Figs $1 F, 4)$. Nerve fibres emerged from this region and passed ventrally between the notochords.

\section{Effects of dorsoventral inversion of the neural tube} with or without the notochord on dorsal root ganglion formation and axon outgrowth (embryos fixed at stages 23-27)

In embryos in which the neural tube was inverted about its dorsoventral axis and allowed to survive for 2 or more days $(n=28)$, HNK-1 immunoreactive cells formed segmentally-arranged dorsal root ganglia adjacent to the neural tube. The results were similar in the presence and absence of the notochord. The ganglia always formed within the rostral half of the sclerotomes. The dorsal root ganglia were often tear-drop shaped. Their orientation was generally normal with respect to the rotated neural tube but inverted relative to the ganglia of the host embryo. In some embryos, however, the ganglia appeared more rounded than normal and sometimes protruded laterally. Occasionally, supernumerary ganglia were observed (Fig. 3C), especially near the junction between rotated and nonrotated portions of the neural tube.

The point of exit of the ventral roots and their initial direction always followed the orientation of the neural tube (Figs 1, 3, 4, 5). However, the presence of a notochord appeared to affect axon trajectory. When the neural tube was inverted in the absence of a notochord, the motor roots appeared to project laterally in the direction of their targets (Fig. 3A,B). When the notochord was located in its normal ventral site and the neural tube had been inverted, the ventral roots generally projected ventrally and circumnavigated the notochord, at the apparent border of the perinotochordal matrix. When the notochord was present in a dorsal 

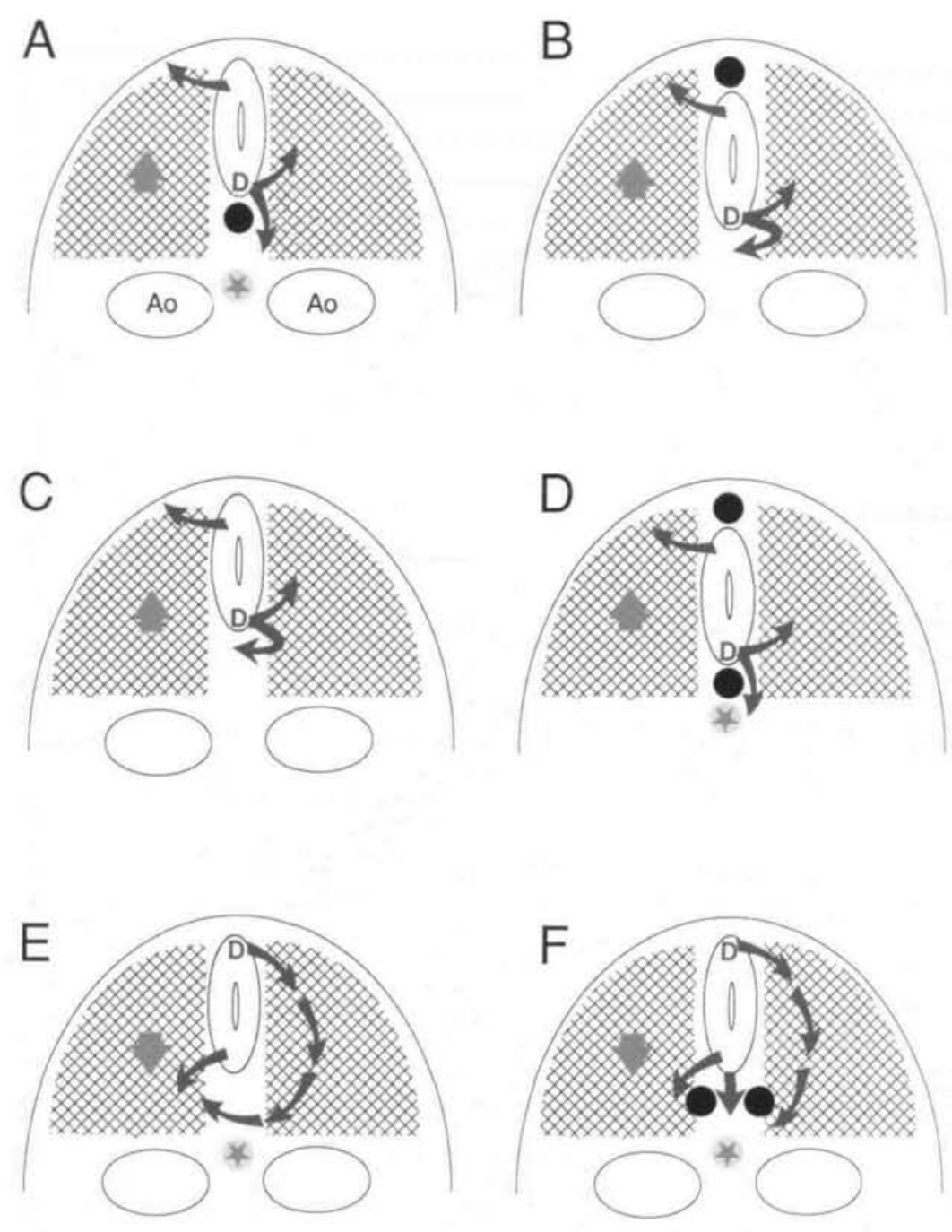

Fig. 1. Diagram summarising the operations performed and the results obtained. The original dorsal edge of the neural tube (neural crest) is marked with a blue ' $D$ '. The somites are shown hatched, the notochord as a black circle and the dorsal aortae (Ao) outlined. The right half of each diagram shows the direction of migration of neural crest cells (blue arrows), as determined from embryos fixed after various incubation times and stained with antibody HNK-1. The left half of each of the diagrams shows the position in which catecholamine fluorescent cells developed (red/yellow star), the orientation of the dorsal root ganglion (red arrow, pointing towards the normal ventral side of the ganglion), and the position of exit and direction of growth of motor axons (green arrows). (A) Neural tube rotation about dorsoventral axis with the notochord in its original position; (B) neural tube and notochord rotation; (C) neural tube rotation with notochord ablated; (D) neural tube rotation with two notochords, one dorsal and one ventral; (E) notochord ablation; (F) notochord implant. 

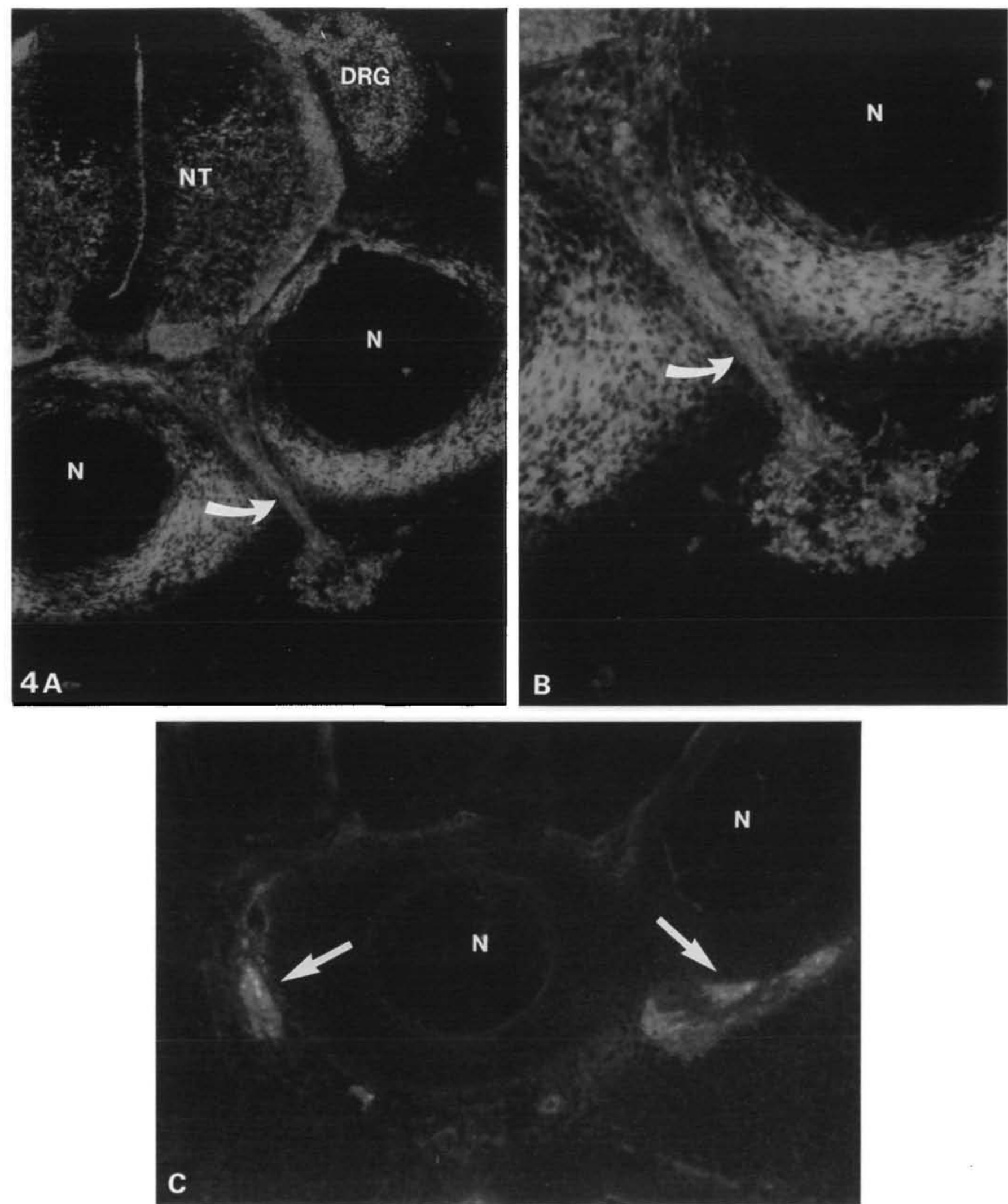

Fig. 4. HNK-1 immunoreactivity (A,B) and catecholamine histofluorescence (C) of an embryo in which an extra notochord (N) was implanted adjacent to the neural tube (NT). B is a higher magnification view of the section shown in A. C illustrates catecholamine histofluorescence (straight arrows) in an adjacent section to that in A and B. The dorsal root ganglia (DRG) appear displaced dorsally and the ventral root fibres (curved arrows) project ventrally between the two notochords. Catecholamine-containing cells are found in ventral sites, close to the aorta and the notochords. 

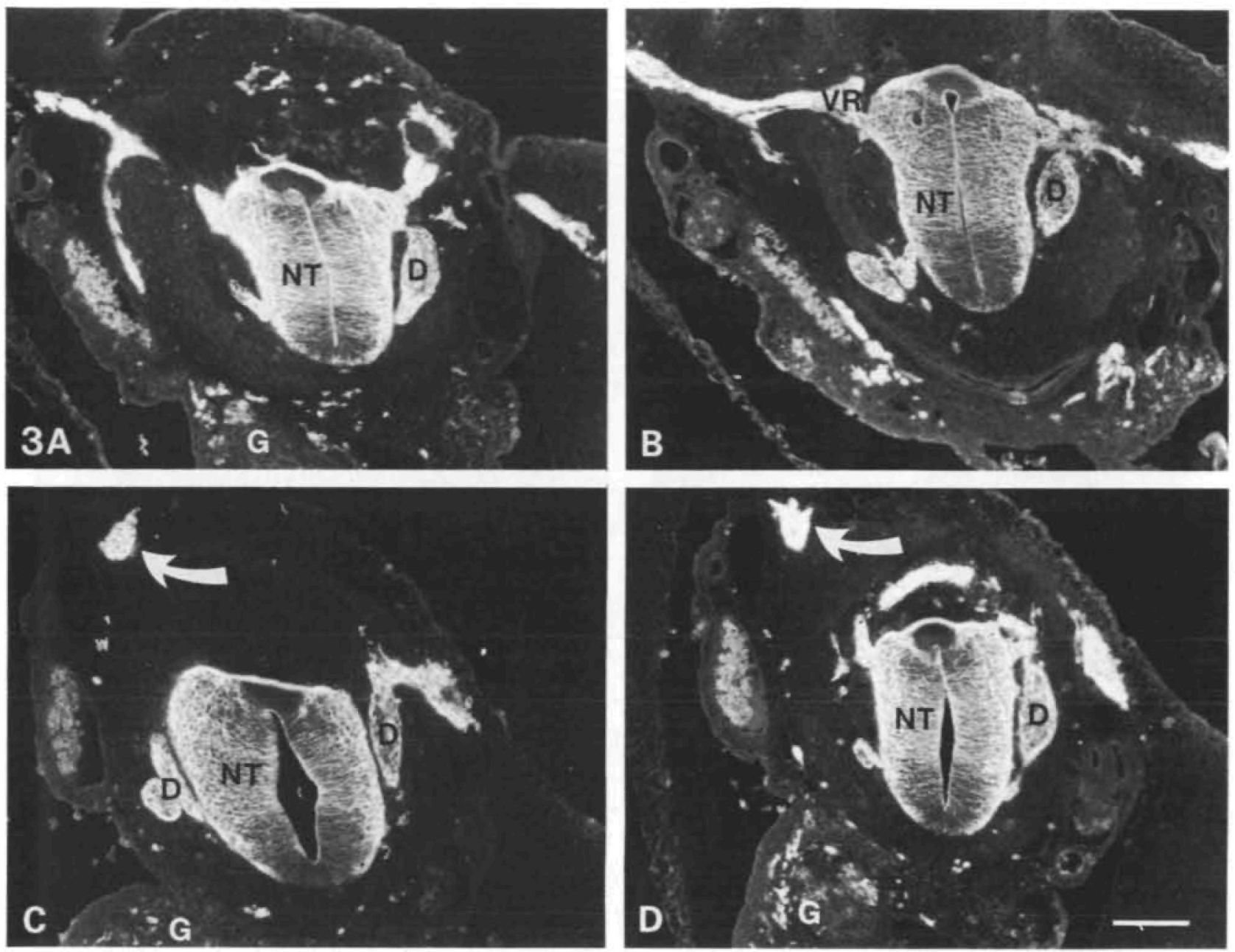

Fig. 3. Fluorescence photomicrographs of transverse sections through an embryo in which the neural tube was rotated $180^{\circ}$ about its dorsoventral axis after extirpation of its notochord. The embryo was fixed at stage 25 , which is well after gangliogenesis normally occurs. The neural tube (NT) formed normally but with inverted dorsoventral polarity. In most sections, the orientation of the dorsal root ganglia (D) follow that of the inverted neural tube. In a few cases, supernumerary dorsal root ganglia can be seen, as illustrated in C. The ventral roots (VR) project from the dorsal portion of the neural tube and appear to find their targets in the limb, as seen in A and B. Aggregates of HNK-1 positive cells (S, curved arrows) form in the dorsal part of the embryo as shown in C and D. Nerve roots (which are also HNK-1 positive) sometimes appear to cross the midline, as shown in $\mathrm{D}$. This behaviour is only seen when the notochord has been extirpated. G, gut. Scale bar, $100 \mu \mathrm{m}$.

location, the ventral roots projected dorsally (Figs 3,5), again circumnavigating the grafted notochord. The dorsal root emerging from an inverted neural tube sometimes projected ventrally or laterally when the notochord was in its normal location, and dorsally or laterally when the notochord was absent or under the dorsal ectoderm. When both a dorsal and ventral notochord were present, some axon tracts projected around the perinotochordal matrix of each notochord. These results suggest that the region surrounding the perinotochordal matrix promotes growth of and/or attracts axons.

\section{Development of catecholaminergic cells in operated embryos}

Catecholamine (aldehyde-induced) fluorescence was seen first in embryos at about stage 25 (approximately 5 days' total incubation; see Enemar et al. 1965). Catecholaminergic cells only differentiated when either the notochord or ventral neural tube was present near the dorsal aorta and mesonephric mesenchyme, although HNK-1-positive cells with sympatheticganglion-like morphology were sometimes found dorsal to the inverted neural tube (Fig. 3C,D; Fig. 5). In embryos in which the neural tube had been rotated dorsoventrally and the notochord was absent $(n=12)$ or present in the dorsal portion of the embryo $(n=7)$, no catecholaminergic cells were observed (Fig. 5A). When . the host notochord was present in its normal position but the neural tube ( $n=11$; Fig. 6 ) or donor neural tube plus notochord $(n=6)$ had been inverted dorsoventrally, catecholaminergic cells differentiated around the aorta and adjacent to the mesonephric mesenchyme (Figs 6, 7). Partial dorsoventral rotation of the neural 


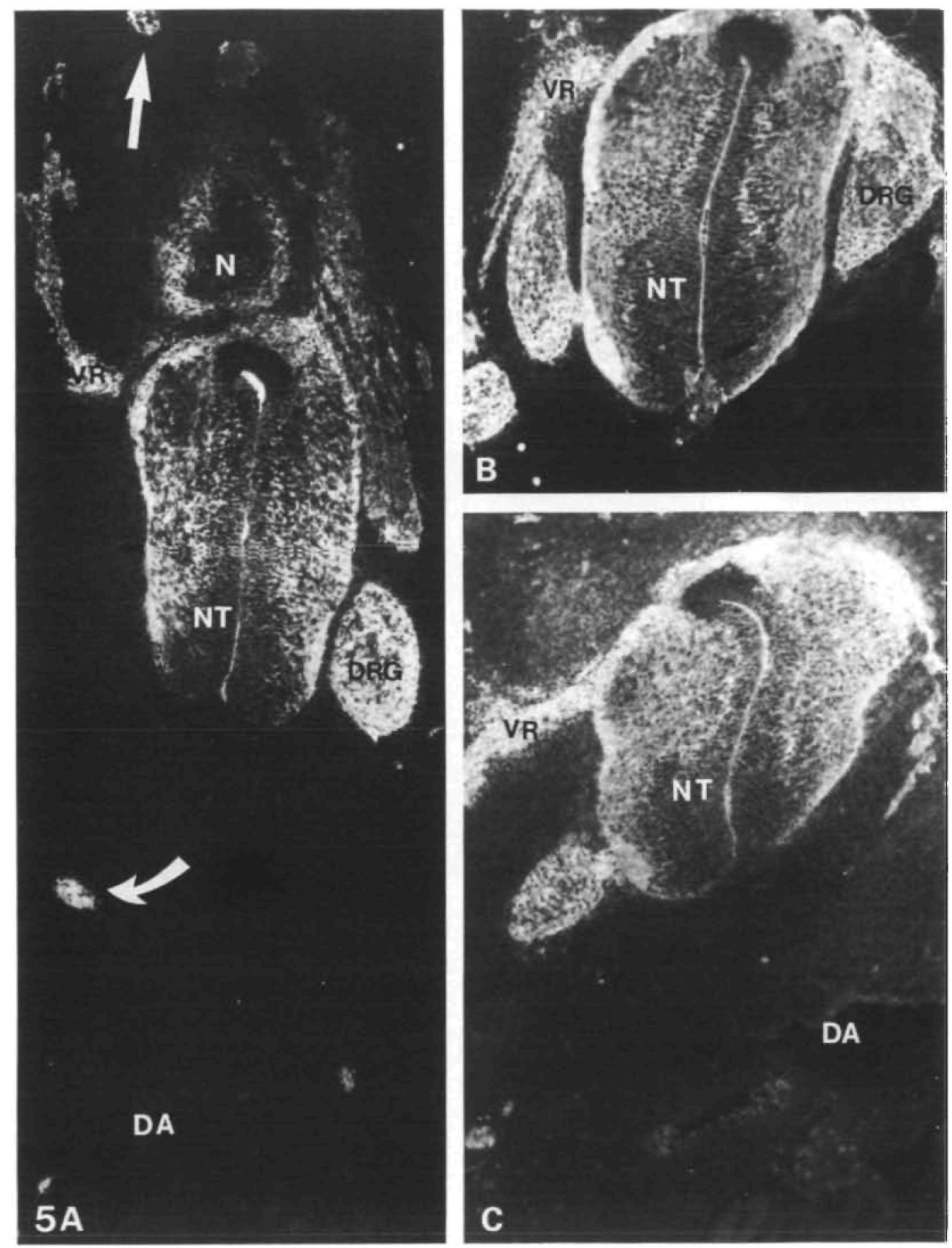

Fig. 5. HNK-1 immunoreactivity of embryos in which the host notochord was removed and a neural tube, with (A), or without $(\mathrm{B}, \mathrm{C})$ a notochord, were inverted by $180^{\circ}$ about the dorsoventral axis. No catecholamine-containing cells were observed in the graft region of these embryos. (A) Ventral root (VR) fibres leave dorsally and project around the dorsally located donor notochord $(\mathrm{N})$. The dorsal root ganglia (DRG) are found adjacent to the neural tube and appear to be normal, apart from their relatively small size, and their orientation follows that of the rotated neural tube. Although HNK1 immunoreactive cells are present ventrally (curved arrow) around the dorsal aorta (DA) and dorsally (straight arrow), no catecholamine-containing cells are observed. (B,C) Another embryo with an inverted neural tube (both host and donor notochords extirpated). The dorsal root ganglia (DRG) formed normally with respect to the inverted neural tube. Ventral root (VR) fibres leave dorsally but appear to project to ventral regions of the embryo or laterally into the limb.

tube $\left(90^{\circ}\right)$ yielded catecholaminergic cells despite the absence of a notochord. Removal of the notochord with the neural. tube remaining in its normal orientation $(n=18)$ also yielded catecholaminergic cells which developed in their normal locations. Thus, the presence of either the ventral neural tube or the notochord is 
necessary for the differentiation of adrenergic derivatives of neural crest cells in the peri-aortic region. However, neither structure appears to be sufficient to elicit adrenergic differentiation in other regions of the embryo.

\section{Discussion}

Pathways taken by migrating neural crest cells and motor axons and the role of the notochord

Our results obtained from embryos in which the neural tube had been rotated about its dorsoventral axis confirm and extend those obtained by Weston (1963). When the tube is rotated so that neural crest cells emerge from a ventral location, the migrating cells take two pathways: one dorsal through the rostral half of the sclerotome and one ventral towards their normal periaortic positions. These results strongly suggest that neural crest cells do not have intrinsic directionality in their migration but rather that they exploit all those areas that are accessible to them and that do not inhibit their migration (such as the segmental plates or the caudal half of the sclerotome; see Bronner-Fraser and Stern, 1991).

It was interesting to observe that the direction of outgrowth of motor axons in all operated embryos tended to be radial, away from their site of origin in the ventral neural tube, regardless of the position of their normal targets such as the limbs. This finding suggests that motor axons grow in this direction because of intrinsic cues or because they are repelled by their site of origin, but not because they are attracted by their targets.

The presence of the notochord, and more specifically of the HNK-1-positive extracellular materials surrounding it, affects the migration of neural crest cells as has been described previously (Newgreen et al. 1986; Pettway et al. 1991), confirming that the notochord is inhibitory to migrating neural crest cells. In addition, we have found that the notochord and its matrix appear to attract motor axons. However, once these axons reach the immediate vicinity of the notochord, they circumnavigate its matrix as if they were inhibited by it. This finding suggests that the extracellular matrix surrounding the notochord is inhibitory for motor axons. It is possible that the chondroitin sulphate proteoglycan(s) thought to be responsible for the inhibition of neural crest migration (Newgreen et al. 1986; Pettway et al. 1991) are also responsible for inhibiting the growth of motor axons.

When an extra notochord had been implanted (Fig. 1F), an additional exit point for motor axons was often seen, and fibres travelled between the two notochords. This finding confirms recent observations (van Straaten et al. 1985a,b; 1989; van Straaten and Drukker, 1987; Jessell et al. 1989) that the notochord, or the matrix surrounding it, induces the floor plate region of the neural tube and the neuroblasts of the adjacent motor columns.

During somite formation, the notochord divides the paraxial mesoderm into left and right halves and its continued presence is required for a bilateral pattern of somites to be maintained (Packard and Jacobson, 1976; Stern and Bellairs, 1984). Here, during crest migration and axon outgrowth, its role also appears to be to generate and maintain bilaterality by preventing the neural crest cells and motor axons from crossing the midline.

\section{Differentiation of neural crest cells}

Our results address three aspects of the differentiation of neural crest cells: (a) the fates of neural crest cells that have migrated abnormally through the embryo, (b) the position and orientation of components of the peripheral nervous system and (c) the factors affecting differentiation of catecholaminergic cells.

\section{(a) Fate of abnormally migrating neural crest cells} In cases of neural tube reversal about its dorsoventral axis, neural crest cells migrate through the rostral halves of the sclerotomes but in reverse direction to their normal pathways. We find, as did Weston (1963), that this reversal in the direction of migration does not prevent the formation of the dorsal root ganglia in their normal location in the rostral half of the sclerotome. We also find that catecholaminergic cells only differentiate in their normal locations, in the region surrounding the aorta. These findings are consistent with the idea that trunk neural crest cells are pluripotent, their fates being determined by the environment in which they find themselves (e.g. Le Douarin et al. 1977, 1979; Le Lièvre et al. 1980; Sieber-Blum and Cohen, 1980; Le Douarin, 1982; Teillet and Le Douarin, 1983; BronnerFraser and Fraser, 1988, 1989; Serbedzija et al. 1989), regardless of the direction of cell migration.

\section{(b) Orientation of components of the peripheral nervous system}

The dorsal root ganglion has a characteristic shape, with a pointed dorsal region from which exit the dorsal root axons, and a blunt ventral region from which arise the axons that migrate towards the peripheral targets. In our experiments, when the neural tube had been rotated (Fig. 1A-D), the pointed dorsal region of the dorsal root ganglion was found ventrally, while in those cases in which the neural tube was in its normal orientation (Fig. 1E,F) the blunt region was found in its normal ventral position.

There are three possible interpretations of this finding. First, it is possible that, as indicated above, the direction of migration of neural crest cells is responsible for the orientation of the ganglia that develop from them. Second, it may be that the proximity of the dorsal portion of the neural tube (the entry point for dorsal root axons) attracts these axons and thus determines the orientation of the ganglia. Third, it is possible that some other cues from the neural tube, such as cues emanating from ventral regions of the neural tube, determine the orientation of the ganglia. It is not possible to discriminate between these three explanations from our results. 

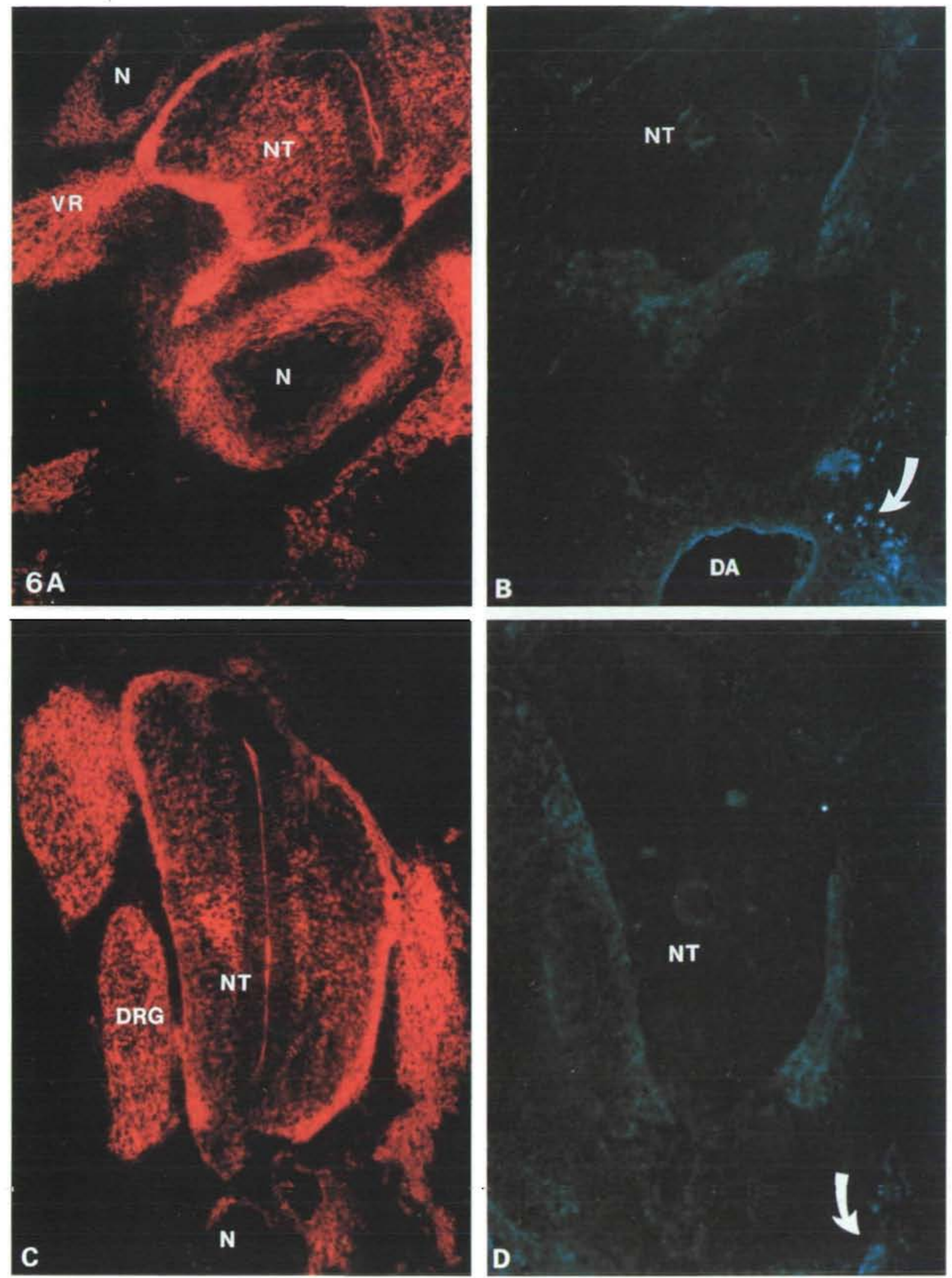

Fig. 6. HNK-1 immunoreactivity $(A, C)$ and catecholamine histofluorescence $(B, D)$ of operated embryos. Dorsal lies towards the top of each photograph. (A) Embryo in which the neural tube (NT) was inverted $180^{\circ}$ about its dorsoventral axis. The notochord of the host was left in its original position. A second notochord from a donor embryo was grafted with the neural tube and appears in a dorsal location. Ventral root (VR) fibres leave the neural tube in the dorsal portion of the embryo, adjacent to the donor notochord. (B) Same section as in A, showing catecholamine-containing cells (curved arrow) adjacent to the dorsal aorta (DA). (C) Embryo in which the neural tube was inverted by $180^{\circ}$ about its dorsoventral axis. The notochord of the host embryo was left in place, and no notochord was grafted with the neural tube. The dorsal root ganglia (DRG) appear relatively normal and their orientation follows that of the rotated neural tube. (D) Same section as in C, showing catecholamine-containing cells (curved arrow) adjacent to the dorsal aorta. In B and D, the more faintly-fluorescing cells surrounding the neural tube are blood cells, which display autofluorescence. N, notochord 

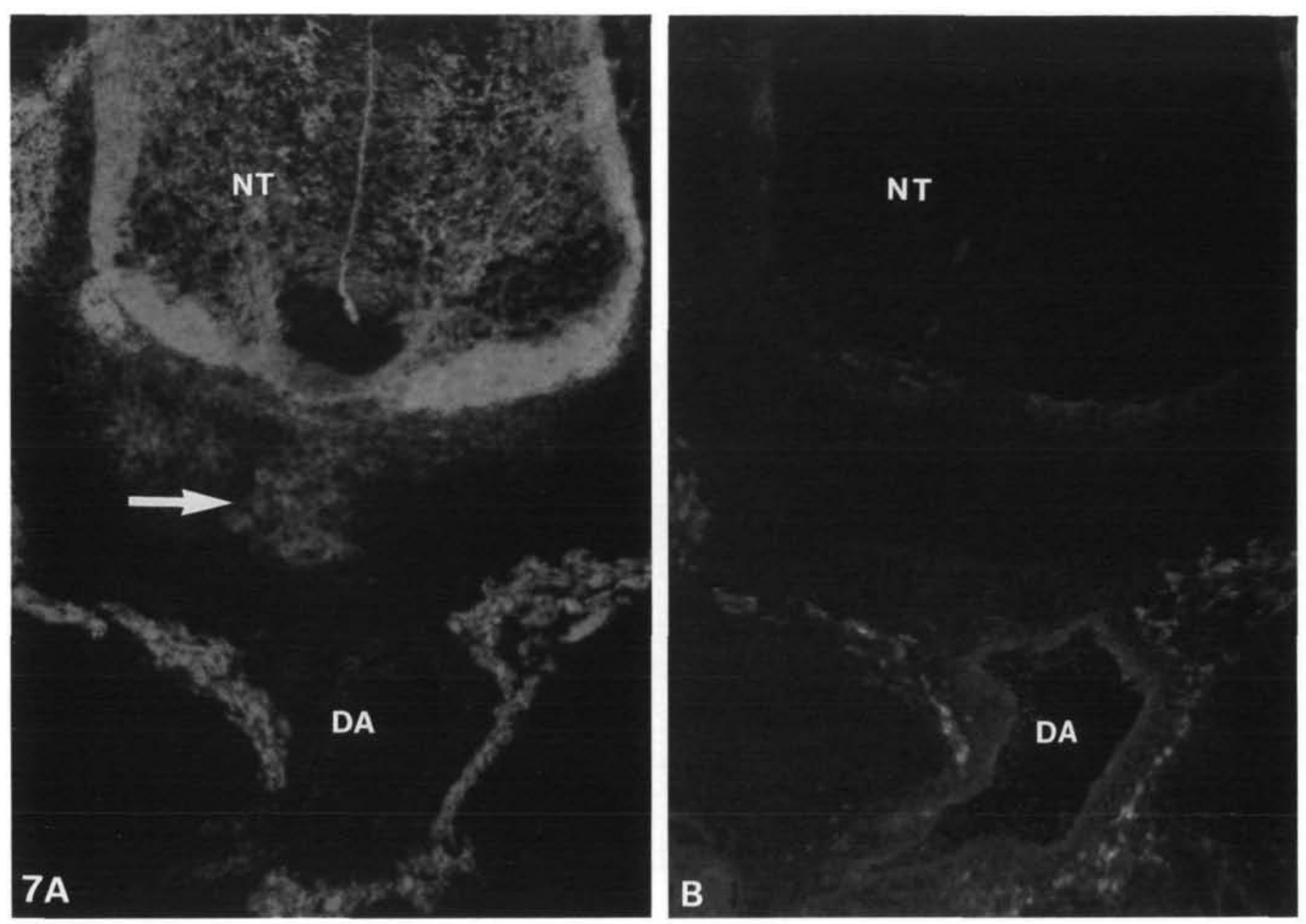

Fig. 7. HNK-1 immunoreactivity (A) and catecholamine histofluorescence (B) of an embryo in which the notochord was removed. (A) The neural tube (NT) is in its normal orientation. A HNK-1-positive matrix (arrow) remains in the region where the notochord would have been, and no HNK-1-positive cells or fibres are seen crossing the midline. Numerous HNK-1-reactive cells are present around the dorsal aorta (DA) and some of these contain catecholamine histofluorescence (B). 


\section{(c) Factors affecting the differentiation of} catecholaminergic cells

In all the embryos in which catecholamine fluorescence was seen, the fluorescent cells were always in their normal, peri-aortic position, in agreement with the findings of Teillet and Le Douarin (1983). Fluorescent cells were never seen dorsally in cases of neural tube or notochord rotation, even though this region sometimes contained HNK-1-positive cells with sympatheticganglion-like morphology (Fig. 3C,D; Fig. 5A). This finding suggests that the environment surrounding the aorta/mesonephros is required for the differentiation of catecholaminergic traits.

In embryos in which the neural tube had been rotated dorsoventrally (see Fig. 1A-D), neural crest cells migrated along two streams: one dorsally through the sclerotome and the other ventrally towards the aorta. It is the latter that must have given rise to the catecholaminergic cells. This result extends the findings of previous investigators (e.g. Cohen, 1972; Norr, 1973; Teillet et al. 1978; Sieber-Blum and Cohen, 1980; Le Douarin, 1982; Teillet and Le Douarin, 1983) who found that somitic cells enhanced sympathetic differentiation in vivo and in vitro. Although somitic cells and fibroblasts stimulate adrenergic differentiation, passage of the neural crest through the somite is clearly not an absolute requirement for the differentiation of these cells.

Teillet and Le Douarin (1983) performed notochord and/or neural tube ablations and examined the differentiation of neural crest cells into their various derivatives. They found that these axial organs are required for the maintenance of somites, through which they affect the differentiation of neural crest derivatives; they also found that the notochord and neural tube play a more direct role on such differentiation. In particular, they argue that the neural tube allows the development of both spinal and sympathetic ganglia even in the absence of a notochord. In turn, when the neural tube has been ablated, the notochord allows the differentiation of sympathetic, but not sensory derivatives.

Our findings extend the pioneering observations of Teillet and Le Douarin (1983) because they suggest that in addition to the normal peri-aortic environment, at least two factors are involved in the control of sympathetic differentiation: the presence of a notochord in its normal ventral location close to the aorta and the presence of a ventral neural tube (floor plate/ventral root region) close to its normal ventral location. Either is sufficient to allow catecholaminergic cells to differentiate near the aorta. At least in the case of the floor plate/ventral root region, proximity appears to suffice, because catecholaminergic cells differentiated in four embryos in which the neural tube had been rotated by only $90^{\circ}$. Again, these findings complement the conclusions of others (Cohen 1972; Norr, 1973; Teillet et al. 1978; Sieber-Blum and Cohen, 1980; Le Douarin, 1982; Teillet and Le Douarin, 1983), who suggested that the neural tube, notochord and somitic cells enhance sympathetic differentiation.
Cohen (1972) and Norr (1973) both reported a stimulatory effect of the ventral neural tube in vitro, but our study represents the first demonstration of this phenomenon in vivo.

The present findings are reminiscent of the results of other experiments (Kalcheim and Le Douarin, 1986) showing that a diffusible signal from the neural tube is required for normal differentiation of neural crest cells into dorsal root ganglia in vivo and adrenergic differentiation of neural crest cells in vitro (Howard and Bronner-Fraser, 1986). It therefore seems likely that sensory and adrenergic differentiation of neural crest cells is modulated by both local and long-range, diffusible factors.

Perhaps the simplest interpretation of our result is that the notochord and the ventral part of the neural tube are both capable of inducing the differentiation of sympathetic cells. The basal portion of the neural tube contains the floor plate, the basal plate and the ventral horn. Of these, the floor plate appears to have most in common with the notochord. The notochord is known to induce the floor plate early in development (van Straaten et al. 1985a,b;1989; van Straaten and Drukker, 1987; Jessell et al. 1989) and the two structures share several antigentic determinants (see Jessell et al. 1989). At least in the chick embryo, however, the floor plate is not derived from notochord cells (Selleck and Stern, 1991).

The effect of the floor plate and/or notochord may not be direct, as suggested by Norr (1973). It is possible, for example, that they act through a prior induction of sclerotome cells. This seems likely in the light of previous suggestions (see above and Cohen, 1972; Norr, 1973; Teillet et al. 1978; Sieber-Blum and Cohen, 1980 ) that extracellular matrix secreted by somite cells (and fibroblasts) increase the number of catecholaminergic cells in clonal cultures of neural crest cells (but see criticisms of some these experiments raised by Le Douarin, 1982; p. 120). As an example of the induction of specific traits in sclerotome cells by the notochord, it is perhaps interesting to mention the observations of Oliver et al. (1988) that sclerotome cells in the vicinity of the notochord express the homeobox gene XIHbox1 (homologous to Hox3.3). Preliminary results (C. D. Stern and E. M. de Robertis, unpublished observations) suggest that the notochord is also responsible for the induction of XlHbox1 long protein expression in the ventral horn of the neural tube. The notochord is also known to be required for differentiation of chondrogenic potential by sclerotome cells (see Strudel, 1955, 1973; Kosher and Lash, 1975).

In conclusion, our results suggest that there is an absolute requirement for proximity of either the ventral region of the neural tube (perhaps the floor plate) or the notochord for the differentiation of catecholaminergic cells in the vicinity of the aorta. This effect may be mediated through prior interactions of the axial structures with the adjacent sclerotome cells. Prior migration of presumptive catecholaminergic cells through the sclerotome, however, is not required for their adrenergic differentiation. 
This work was supported by USPHS grants HD-25138 and HD-15527 and a grant from the Muscular Dystrophy Association to M. B-F. and by a grant from the Medical Research Council and a Wellcome Trust travel grant to C.D.S. M. B-F. is a Sloan Foundation Fellow.

\section{References}

Bronner-FraSer, M. (1986). Analysis of the early stages of trunk neural crest cell migration in avian embryos using monoclonal antibody HNK-1. Devl Biol. 115, 44-55.

Bronner-Fraser, M. and Fraser, S. (1989). Developmental potential of avian trunk neural crest cells in situ. Neuron 3 755-766

Bronner-Fraser, M. and Fraser, S. E. (1988). Cell lineage analysis reveals multipotency of some avian neural crest cells. Nature 335, 161-163.

Bronner-Fraser, M. and Stern, C. D. (1991). Effects of mesodermal tissues on avian neural crest cell migration. Devl Biol. 143, 213-217.

Conen, A. M. (1972). Factors directing the expression of sympathetic nerve traits in cells of neural crest origin. $J$. exp. Zool. 179, 167-182.

Enemar, A., Falck, B. and Hakanson, R. (1965). Observations on the appearance of norepinephrine in the sympathetic nervous system of the chick embryo. Devl Biol. 11, 268-283.

Hamburger, V. and Hamilton, H. L. (1951). A series of normal stages in the development of the chick. J. Morph. 88, 49-92.

Howard, M. and Bronner-Fraser, M. (1986). Neural tube derived factors influence the differentiation of neural crest cells in vitro: Effects on activity of neurotransmitter biosynthetic enzymes. Devl Biol. 117, 45-54.

Jessell, T. M., Bovolenta, P., Placzek, M., Tessier-Lavigne, M. AND DodD, J. (1989). Polarity and patterning in the neural tube: the origin and function of the floor plate. In Cellular Basis of Morphogenesis (ed. D. Evered and J. Marsh). Chichester: Wiley and Sons. Ciba Foundation Symposium 144, 255-280.

Kalcheim, C. And Le Douarin, N. M. (1986). Requirement of a neural tube signal for the differentiation of neural crest cells into dorsal root ganglia. Devl Biol. 116, 451-466.

Keynes, R. J. AND STERn, C. D. (1988). Mechanisms of vertebrate segmentation. Development 103, 413-429.

KOSHER, R. L. AND LASH, J. W. (1975). Notochordal stimulation of in vitro somite chondrogenesis before and after enzymatic removal of perinotochordal materials. Devl Biol. 42, 362-378

Lallier, T. AND Bronner-Fraser, M. (1988). A spatial and temporal analysis of dorsal root and sympathetic ganglion formation in the avian embryo. Devl Biol. 127, 99-112.

Le Douarin, N. M. (1982). The Neural Crest. Cambridge: Cambridge University Press.

Le Douarin, N. M., Le Lièvre, C. S., Schweizer, G. ANd Ziller, C. M. (1979). An analysis of cell line segregation in the neural crest. In Cell Lineage, Stem Cells and Cell Determination (ed. N. Le Douarin). Amsterdam: Elsevier/North Holland. pp. 353-365.

Le douarin, N. M. and Teillet, M. A. (1973). The migration of neural crest cells to the wall of the digestive tract in avian embryo. J. Embryol. exp. Morph. 30, 31-48.

Le Douarin, N. M., Teillet, M. A. and Le Lièvre, C. S. (1977). Influence of the tissue environment on the differentiation of neural crest cells. In Cell and Tissue Interactions (ed. J. W. Lash and M. M. Burger). New York: Raven Press. pp. 11-27.

Le Lièvre, C. S., Schweizer, G. G., Ziller, C. M. and Le DouARIN, N. M. (1980). Restrictions of developmental capabilities in neural crest cell derivatives as tested by in vivo transplantation experiments. Devl Biol. 77, 362-378.

Loring, J. F. AND ERICKSON, C. A. (1987). Neural crest cell migratory pathways in the trunk of the chick embryo. Devl Biol. $121,220-236$.
Newgreen, D. F., Scheel, M. And Kastner, V. (1986) Morphogenesis of sclerotome and neural crest in avian embryos: in vivo and in vitro studies on the role of notochordal extracellular matrix. Cell Tiss. Res. 244, 299-313.

NorR, S. C. (1973). In vitro analysis of sympathetic neuron differentiation from chick neural crest cells. Devl Biol. 34, $16-38$

Oliver, G., Wright, C. V. E., Hardwicke, J. and de Robertis E. M. (1988). Differential antero-posterior expression of two proteins encoded by a homeobox gene in Xenopus and mouse embryos. EMBO J. 7, 3199-3209.

Packard, D. S. And Jacobson, A. G. (1976). The influence of axial structures on chick somite formation. Devl Biol. 53. 36-48.

Pettway, Z., Guillory, G. and Bronner-Fraser, M. (1991). Absence of neural crest cells from the region surrounding implanted notochords in situ. Devl Biol. (in press).

Rickmann, M., Fawcett, J. W. and Keynes, R. J. (1985). The migration of neural crest cells and the growth of motor axons through the rostral half of the chick somite. J. Embryol. exp. Morph. 90, 437-455.

Sechrist, J., Coulombe, J. N. and Bronner-Fraser, M. (1989). Combined vital dye labelling and catecholamine histofluorescence of transplanted ciliary ganglion cells. J. Neural Transpl. 1, 113-128.

Selleck, M. A. J. And Stern, C. D. (1991). Fate mapping and cell lineage analysis of Hensen's node in the chick embryo. Development 112, 615-626.

Serbedzija, G. N., Bronner-Fraser, M. and Fraser, S. E (1989). A vital dye analysis of the timing and pathways of avian trunk neural crest cell migration. Development 106, 809-816.

Sieber-Blum, M. ANd Cohen, A. M. (1980). Clonal analysis of quail neural crest cells: they are pluripotent and differentiate in vitro in the absence of non-crest cells. Devl Biol. 80, 96-106.

Stern, C. D. And Bellairs, R. (1984). The roles of node regression and elongation of the area pellucida in the formation of somites in avian embryos. J. Embryol. exp. Morph. 81, 75-92.

Stern, C. D. And Keynes, R. J. (1987). Interactions between somite cells: the formation and maintenance of segment boundaries in the chick embryo. Development 99, 261-272.

Strudel, G. (1955). L'action morphogène du tube nerveux et de la corde sur la différenciation des vertèbres et des muscles vertebraux chez l'embryon de poulet. Arch. Anat. Microsc. Morphol. exp. 44, 209-235.

STRUdel, G. (1973). Matériel extracellulaire periaxial et chondrogenèse vertébrale. Année Biol. 12, 401-416.

Teillet, M. A., Cochard, P. And Le Douarin, N. M. (1978). Relative roles of the mesenchymal tissues and of the complex neural tube-notochord on the expression of adrenergic metabolism in neural crest cells. Zoon 6, 115-122.

Teillet, M. A., Kalcheim, C. And Le Douarin, N. M. (1987). Formation of the dorsal root ganglion in the avian embryo: segmental origin and migratory behavior of neural crest progenitor cells. Devl Biol. 120, 329-347.

Teillet, M. A. And Le Douarin, N. M. (1983). Consequences of neural tube and notochord excision on the development of the peripheral nervous system in the chick embryo. Devl Biol. 98, 192-211.

Tucker, G. C., Aoyama, H., Lipinski, M., Tursz, T. and THIERY, J.-P. (1984). Identical reactivity of monoclonal antibodies HNK-1 and NC-1: conservtion in vertebrates on cells derived from neural primordium and on some leukocytes. Cell Diffn. 14, 223-230.

van Straaten, H. W. M. and Drukker, J. (1987). Influence of the notochord on the morphogenesis of the neural tube. In Mesenchymal-epithelial Interactions in Neural Development (eds J. R. Wolff, J. Sievers and M. Berry). Berlin: Springer Verlag. (NATO/ASI Series H No5), pp. 153-162.

van Straaten, H. W. M., Hekking, J. W. M., Beursgens, J. P. W. M., Terwindt-Rouwenhorst, E. ANd DrukKer, J. (1989). Effect of the notochord on proliferation and differentiation in 
the neural tube of the chick embryo. Development 107, $793-803$.

van Straaten, H. W. M., Hekking, J. W. M., Thors, F.

WIERTZ, E. L. J. M. AND DRUKKER, J. (1985a). Induction of an additional floor plate in the neural tube. Acta Morphol. Neerl. Scand. 23, 91-97.

van Straaten, H. W. M., Thors, F., Hoessels, E. L., Hekking,

J. W. M. AND DRUKKer, J. (1985b). Effect of a notochordal implant on the early morphogenesis of the neural tube and neuroblasts. Devl Biol. 110, 247-254.

WESTON, J. (1963). A radioautographic analysis of the migration and localization of trunk neural crest cells in the chick. Devl Biol. 6, 279-310. 